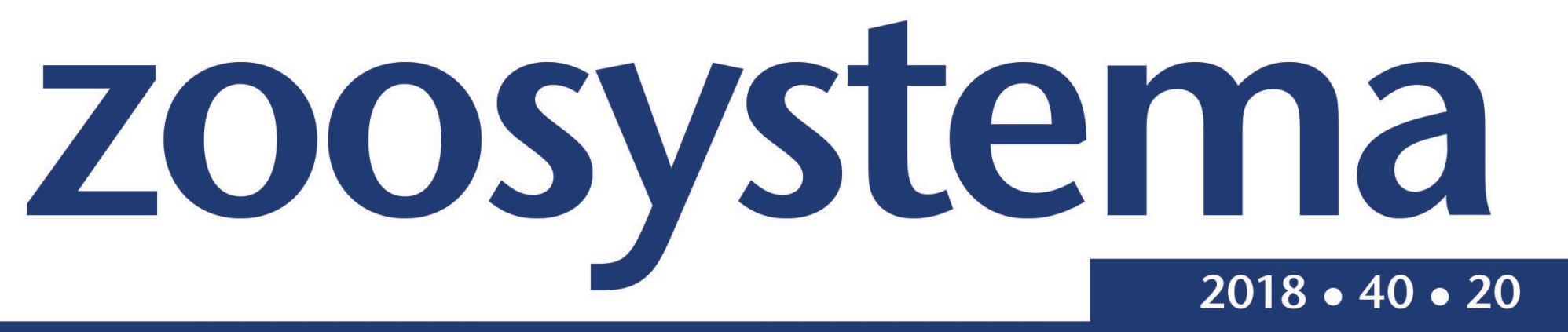

New species of Dolichopoda Bolívar, 1880 (Orthoptera, Rhaphidophoridae) from the Aegean Islands of Andros, Paros and Kinaros (Greece)

Claudio DI RUSSO, Mauro RAMPINI, Claudio CHIMENTI \& Sotiris ALEXIOU 
DiRECTEUR DE LA PUBlication: Bruno David

Président du Muséum national d'Histoire naturelle

RÉDACTRICE EN CHEF / EDITOR-IN-CHIEF : Laure Desutter-Grandcolas

AssistanTS DE RÉDACTION / AsSISTANT EDITORS: Anne Mabille (zoosyst@mnhn.fr), Emmanuel Côtez

Mise en PAge / PAgE LAYOUt: Anne Mabille

COMITÉ SCIENTIFIQUE / SCIENTIFIC BOARD:

James Carpenter (AMNH, New York, États-Unis)

Maria Marta Cigliano (Museo de La Plata, La Plata, Argentine)

Henrik Enghoff (NHMD, Copenhague, Danemark)

Rafael Marquez (CSIC, Madrid, Espagne)

Peter Ng (University of Singapore)

Norman I. Platnick (AMNH, New York, États-Unis)

Jean-Yves Rasplus (INRA, Montferrier-sur-Lez, France)

Jean-François Silvain (IRD, Gif-sur-Yvette, France)

Wanda M. Weiner (Polish Academy of Sciences, Cracovie, Pologne)

John Wenzel (The Ohio State University, Columbus, États-Unis)

COUVERTURE / COVER:

Female habitus of Dolichopoda kikladica Di Russo \& Rampini, n. sp. Photo by G. Anousakis.

\author{
Zoosystema est indexé dans / Zoosystema is indexed in: \\ - Science Citation Index Expanded (SciSearch ${ }^{\circledR}$ ) \\ - ISI Alerting Services ${ }^{\circledR}$ \\ - Current Contents ${ }^{\circledR}$ / Agriculture, Biology, and Environmental Sciences ${ }^{\circledR}$ \\ - Scopus ${ }^{\circledR}$
}

Zoosystema est distribué en version électronique par / Zoosystema is distributed electronically by:

- BioOne ${ }^{\circledR}$ (http://www.bioone.org)

Les articles ainsi que les nouveautés nomenclaturales publiés dans Zoosystema sont référencés par / Articles and nomenclatural novelties published in Zoosystema are referenced by:

- ZooBank ${ }^{\circledR}$ (http://zoobank.org)

Zoosystema est une revue en flux continu publiée par les Publications scientifiques du Muséum, Paris / Zoosystema is a fast track journal published by the Museum Science Press, Paris

Les Publications scientifiques du Muséum publient aussi / The Museum Science Press also publish:

Adansonia, Anthropozoologica, European Journal of Taxonomy, Geodiversitas, Naturae.

Diffusion - Publications scientifiques Muséum national d'Histoire naturelle

CP 41 - 57 rue Cuvier F-75231 Paris cedex 05 (France)

Tél. : 33 (0)1 40794805 / Fax: 33 (0)1 40793840

diff.pub@mnhn.fr / http://sciencepress.mnhn.fr

(C) Publications scientifiques du Muséum national d'Histoire naturelle, Paris, 2018

ISSN (imprimé / print): 1280-9551/ ISSN (électronique / electronic): 1638-9387

PHOTOCOPIES :

Les Publications scientifiques du Muséum adhèrent au Centre Français d'Exploitation du Droit de Copie (CFC), 20 rue des Grands Augustins, 75006

Paris. Le CFC est membre de l'International Federation of Reproduction Rights Organisations (IFRRO). Aux États-Unis d'Amérique, contacter le Copyright Clearance Center, 27 Congress Street, Salem, Massachusetts 01970.
PHOTOCOPIES:

The Publications scientifiques du Muséum adhere to the Centre Français d'Exploitation du Droit de Copie (CFC), 20 rue des Grands Augustins, 75006 Paris. The CFC is a member of International Federation of Reproduction Rights Organisations (IFRRO). In USA, contact the Copyright Clearance Center, 27 Congress Street, Salem, Massachusetts 01970. 


\title{
New species of Dolichopoda Bolívar, 1880 (Orthoptera, Rhaphidophoridae) from the Aegean Islands of Andros, Paros and Kinaros (Greece)
}

\author{
Claudio DI RUSSO \\ Mauro RAMPINI \\ Claudio CHIMENTI \\ Laboratorio di Biospeleologia, Dipartimento di Biologia e Biotecnologie "C. Darwin", \\ Università di Roma La Sapienza, Viale dell'Università 32, I - Roma (Italy) \\ beagle.amb@inwind.it (corresponding author) \\ mauro.rampini@uniroma1.it \\ claudio.chimenti@uniroma1.it
}

Sotiris ALEXIOU

DIL Deutsches Institute für Lebensmitteltechnik e.V., Prof.-von-Klitzing-Str. 7, D-49610, Quakenbrück, Niedersachsen (Germany) s.alexiou@dil-ev.de

Submitted on 20 November 2017 | Accepted on 8 May 2018 | Published on 16 October 2018

urn:Isid:zoobank.org:pub:99BDA91A-0C1E-4B06-9766-12741B593454

Di Russo C., Rampini M., Chimenti C. \& Alexiou S. 2018. - New species of Dolichopoda Bolívar, 1880 (Orthoptera, Rhaphidophoridae) from the Aegean Islands of Andros, Paros and Kinaros (Greece). Zoosystema 40 (20): $469-479$. https://doi.org/10.5252/zoosystema2018v40a20. http://zoosystema.com/40/20

\section{ABSTRACT}

In this paper two new species of Dolichopoda Bolívar, 1880 from the Cyclades islands of Andros and Paros and one from the Dodecanissos island of Kinaros, are described, increasing the total number of Greek species to 32. The new species from Paros (D. kikladica Di Russo \& Rampini, n. sp.) and Kinaros (D. margiolis Di Russo \& Rampini, n. sp.) show strong similarities with D. naxia Boudou-Saltet, 1972 from Naxos forming

KEY WORDS Cyclades,

Dodecanese,

Aegean Sea,

biogeography, new species

MOTS CLÉS Cyclades,

Dodecanese, mer Egée,

biogeographie, espèces nouvelles. an homogenous group limited to the central Aegean islands. On the other hand the species D. christos-nifoni Di Russo \& Rampini, n. sp. from Andros shows a combination of morphological characters that partly resemble characters found in Evvian Dolichopoda, and partly in species from the Cyclades. Relationships among these three new taxa and the other adjacent Dolichopoda species are discussed on the basis of the paleogeological and paleoclimatic events that shaped the present geography of the Aegean area.

\section{RÉSUMÉ}

Nouvelles espèces de Dolichopoda Bolivar, 1880 (Orthoptera, Rhaphidophoridae) des îles égéennes d'Andros, de Paros et de Kinaros (Grèce).

Dans cet article, deux nouvelles espèces de Dolichopoda Bolívar, 1880 sont décrites des îles Cyclades, Andros et Paros, et une autre des îles Dodecanissos, Kinaros, portant à 32 le nombre total d'espèces grecques. Deux de ces espèces, D. kikladica Di Russo \& Rampini, n. sp. de Paros et $D$. margiolis Di Russo \& Rampini, n. sp. de Kinaros, présentent de fortes similitudes avec D. naxia Boudou-Saltet, 1972 endémique de Naxos, formant un groupe homogène limité aux îles égéennes centrales. D'autre part, l'espèce $D$. christos-nifoni Di Russo \& Rampini, n. sp. d'Andros présente une combinaison de caractères morphologiques, qui ressemblent en partie à des caractères trouvés dans les Dolichopoda d'Eubée, et, en partie, à des caractères des espèces des Cyclades. Les relations entre ces trois nouveaux taxons et les autres espèces de Dolichopoda proches géographiquement sont discutées sur la base des événements paléogéologiques et paléoclimatiques qui ont façonné la géographie actuelle de la région égéenne. 


\section{INTRODUCTION}

Dolichopoda Bolívar, 1880 is species rich genus of Cave crickets belonging to the Rhaphidophoridae Walker, 1871. It is widely distributed throughout the northern part of the Mediterranean. The highest concentration of species is found in the eastern part of the Mediterranean in Greece and Turkey. The first two species of Dolichopoda from Greece were described by Chopard (1934) who added another six species in the following 30 years (Chopard 1954, 1955, 1964) bringing the total to eight. Boudou-Saltet took over from Chopard and between 1970 and 1980 described another nine new species (Boudou-Saltet 1970, 1971a, b, 1972a, b, 1973a, b, 1980) bringing the total up to 17 by 1980 . Then, with the exception of a single species described in 2002 (Galvagni 2002) no more Greek species were described in Dolichopoda for almost 30 years until 2008. From that year onwards another 11 new species of Dolichopoda have been described, bringing the total number of species to 29 , all of which except one (D. remyi Chopard, 1934) are endemic to Greece.

The genus is represented in the Aegean islands with 10 species: Dolichopoda thasosensis Chopard, 1964 (Thassos); D. saraolacosi Rampini \& Di Russo, 2015 (Skyros); D. makrykapa Boudou-Saltet, 1980 (Evvia); D. ochtoniai Rampini \& Di Russo, 2015 (Evvia); D. cassagnaui BoudouSaltet, 1971 (Evvia); D. giulianae Rampini \& Di Russo, 2012 (Samos); D. kalithea Di Russo \& Rampini, 2012 (Samos); D. calidnae Rampini \& Di Russo, 2012 (Kalimnos); D. naxia Boudou-Saltet, 1972 (Naxos); and D. paraskevi Boudou-Saltet, 1973 (Kriti) (Fig. 1) (Alexiou et al. 2013, 2015; Di Russo et al. 2014). In this paper we present the description of two new species from the Cyclades islands, Andros and Paros, and one from the Dodecanissos islands, Kinaros. Thus, the number of Greek species of Dolichopoda increases to 32, from which 13 occur on the Aegean islands.

\section{MATERIAL AND METHODS}

The specimens studied were all collected by hand on the wall of caves during field trips to Paros (G. Anousakis in 2014) and Andros (S. Alexiou in 2015). The collection of the sole specimen from Kinaros (A. Margiolis in 2016) was done accidentally and from the surface. Specimens were preserved in $70 \%$ ethanol and deposited in the collection of the $\mathrm{Mu}-$ seum of Zoology of the University "La Sapienza" of Rome, Italy (MZUR). Duplicates are deposited in the collection of Zoological Museum of the University of Athens (ZMUA) and collection of S. Alexiou (coll. SA). Permissions for collection of samples were obtained from the Ephorate of Palaeoanthropology and Speleology of the Ministry of Culture, Education and Religious Affairs, Athens. The specimens were studied with a Leica MZ12.5 stereomicroscope. All measurements are in mm. Photographs were taken with a Samsung NX digital camera. The photographs and distribution map were processed using ACD See Pro 8. For the morphological analysis seven external body characters were utilized: shape of the lobes of the tergum X; median process of the epiphallus; shape of the epiphallus; plica dorsalis (sensu Gorochov \& Unal 2015); amount of spinulation of the hind tibia; shape of the female subgenital plate; number of denticles on the inner valvae of the ovipositor.

\section{SYSTEMATICS}

Family RHAPHIDOPHORIDAE Walker, 1871 Genus Dolichopoda Bolívar, 1880

\section{Dolichopoda kikladica}

Di Russo \& Rampini, n. sp.

(Fig. 2)

\section{urn:Isid:zoobank.org:act:48A31226-BB4F-487F-91F2-540D345C7E4B}

Type Material. - Holotype. Cyclades (Kiklades), Paros Isl., Langada, Cave Ton Demonon, $37^{\circ} 01.092^{\prime} \mathrm{N}, 25^{\circ} 12.560^{\prime} \mathrm{E}, 457 \mathrm{~m}, 10^{\prime \prime}$, 07.XII.2014, G. Anousakis leg. (MZUR).

OTHER MATERIAL EXAMINED. $-20^{7}$ (MZUR), 4 nymphs, same locality, date and collector as the holotype (ZMUA).

TyPe LOCALITy. - Paros is the third largest island of the Cyclades, with a size of $196 \mathrm{~km}^{2}$. The cave Ton Demonon ('cave of the demons') or Cave of Kalampakis is located south-east of Paros town, in the Langada area, near Marpissa village. It opens on a small hill, in the SW part of the main massif of the island, Agioi Pantes $(771 \mathrm{~m})$. A walking distance of $15^{\prime}$ is needed to reach the entrance. According to a local myth, a monk imprisoned the demons of the island inside the cave, hence the name. Cave Ton Demonon was explored at 1969 by the member of Hellenic Speleological Society (H.S.S.) Anna Petrochilou and the results were published the next year (Petrochilou 1970). She is the first to report the presence of a Dolichopoda population (as D. petrochilosi Chopard, 1954). The entrance of the cave is $1.4 \times 2.5 \mathrm{~m}$ and faces south-east. The size of the cave is about $500 \mathrm{~m}^{2}$. The temperature is $18^{\circ} \mathrm{C}$ and the humidity is $85 \%$.

Etymology. - The new species name refers to the Cyclades (Kiklades) archipelagos.

DiAGNOSIS. - Closely resembling $D$. naxia, differing mainly in the uniformly yellowish coloration of the body, the different amount of the leg spinulation, the different shape of the male tenth tergum, the median process of the epiphallus being less elongated and more thickened with the anterior basal processes without ridges.

\section{DESCRIPTION}

Male

Size relatively big. Body uniformly light brown-yellowish with the posterior margins of the terga darker (Fig. 2A). Legs elongated, femora unarmed. Fore tibiae armed with $6 / 7$ spines on both sides of lower edge, 2/4 spines along upper edge and two apical spurs of equal length. Mid tibiae with $5 / 6$ spines on lower edge, $3 / 6$ short spines on both sides of upper edge, and two apical spurs similar to those of fore tibia. Hind tibiae longer with $18 / 20$ spines of varying length on both sides of upper edge and 3/4 homogeneous spines 


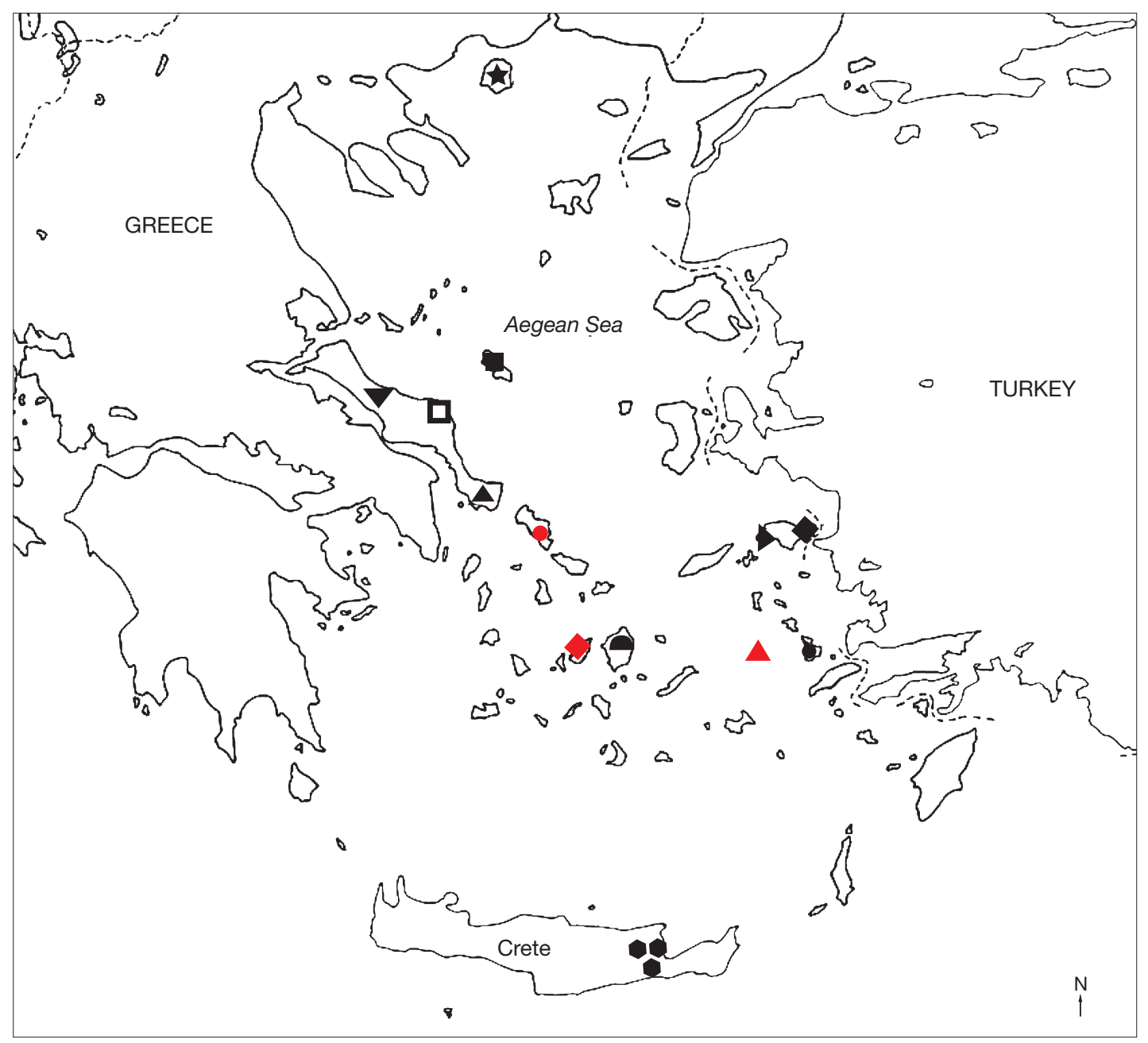

FIG. 1. - Geographical distribution of the Aegean Dolichopoda species, including the new species described in this paper: $\star$, Dolichopoda thasosensis Chopard, 1964; - D. saraolacosi Rampini \& Di Russo, 2015; 口, D. ochtoniai Rampini \& Di Russo, 2015; $\mathbf{\nabla}$, D. makrykapa Boudou-Saltet, 1980; $\boldsymbol{\Delta}$, D. cassagnaui Boudou-Saltet, 1971; $\longrightarrow$, D. kalithea Di Russo \& Rampini, 2012; , D. giulianae Rampini \& Di Russo, 2012; •, D. calidnae Rampini \& Di Russo, 2012; •, D. naxia Boudou-Saltet, 1972; , D. christos-nifoni Di Russo \& Rampini, n. sp.; $\bullet$, D. kikladica Di Russo \& Rampini, n. sp.; $\Delta$, D. margiolis Di Russo \& Rampini, n. sp.; - D. paraskevi Boudou-Saltet, 1973.

along lower edge. Tenth tergum with two lateral, trapezoid lobes separated by a wide concave margin slightly incised in the middle (Fig. 2B). Subgenital plate wide, globular with short lateral lobes (Fig. 2C). Cylindrical styli inserted at the apex of the plate where an evident incision occurs (Fig. 2D). Epiphallus strongly sclerotized showing a cylindrical median process, acute at the apex (Fig. 2E); from the side, median process lightly curved only in distal part; basal processes rather enlarged, with the posterior ones more developed (Fig. 2F). Plica dorsalis wide, formed by two basal lobes well developed and slightly sclerotized. Apical lobe arched showing a few denticles on external margin and in the middle, an apically curved protuberance occur (Fig. 2G).

Length $(\mathrm{mm})$ : body 17.00; pronotum 3.3; fore femora 15.00; middle femora 14.0; hind femora 18.2; fore tibia 17.00; middle tibia 17.00; hind tibia 21.8; hind tarsus 8.3; 1 st article of hind tarsus 4.2 .

\section{Female}

Unknown.

REMARK

The authors became involved with the Paros population when Anna Tsigonia, a resident of Paros, participated in a speleological excursion to Ton Demonon cave, organized by Giorgos Anousakis, member of Hellenic Speleological Society and also resident of the island. She posted on Facebook a picture of a Dolichopoda she took during that excursion, which came to the authors' attention. Both Tsigonia and Anousakis were contacted, and the result was that the latter, accompanied by Vasilis Tsigonias, undertook the task to collect samples and locate other populations on the island. The species seems to be widely spread on the main mountain massif of Paros, Mt Agioi Pantes, as well as on smaller marginal hills. 
Except for the type locality, cave cricket populations obviously belonging to the same species were observed in six other caves or old mines of the island, all by Giorgos Anousakis and Vasilis Tsigonias: a) cave of Agios Georgios $\left(37^{\circ} 01.287^{\prime} \mathrm{N}, 025^{\circ} 12.776^{\prime} \mathrm{E}\right)$, on the same hill and on the same day as the type material. This is a much smaller cave situated at an altitude of $358 \mathrm{~m}$, a few meters away from the Monastery of Agios Georgios; b) cave of Krevatarias $\left(37^{\circ} 02.802^{\prime} \mathrm{N}, 025^{\circ} 10.889^{\prime} \mathrm{E}\right)$, visited on 28.XII.2014, situated on Mt Agioi Pantes, at the altitude of $656 \mathrm{~m}$; c) unnamed pitfall $\left(37^{\circ} 01.410^{\prime} \mathrm{N}, 025^{\circ} 11.169^{\prime} \mathrm{E}\right)$, at the area of Langada, south of Paros town, at an altitude of $610 \mathrm{~m}$, visited on 18.IV.2015; d) two abandoned mines, a few meters away from each other, $\left(37^{\circ} 03.267^{\prime} \mathrm{N}, 025^{\circ} 09.876^{\prime} \mathrm{E}\right)$, at the area of Aliparta, west of the town of Paros, at an altitude of $455 \mathrm{~m}$, visited on 11.XII.2016; e) cave To Moutsno $\left(37^{\circ} 03.216^{\prime} \mathrm{N}\right.$, $\left.025^{\circ} 11.039^{\prime} \mathrm{E}\right)$, Mt Agioi Pantes, at an altitude of $557 \mathrm{~m}$, visited on 02.IV.2017; and f) Pitfall Sti Xoni ( $37^{\circ} 02.224^{\prime} \mathrm{N}$, $\left.025^{\circ} 11.189^{\prime} \mathrm{E}\right), \mathrm{Mt}$ Agioi Pantes, at an altitude of $584 \mathrm{~m}$, visited on 27.IV.2017.

\section{Dolichopoda margiolis \\ Di Russo \& Rampini, n. sp.} (Fig. 3)

\section{urn:Isid:zoobank.org:act:AC794442-78C6-4585-8E1C-BB9708BCBA92}

Type Material. - Holotype. Dodecanissos, Kinaros island, $10^{\prime \prime}$, 12.II.2016, A. Margiolis leg. (epigean) (MZUR).

TYPE LOCALITY. - Kinaros is a small islet of $4.5 \mathrm{~km}^{2}$, that lies east of Amorgos and west of Leros. The highest point of the islet is $296 \mathrm{~m}$. The islet is long and narrow with steep, inaccessible shores. This small windswept island, along with the nearby Levitha, lies isolated in between Cyclades and eastern Aegean islands. Although zoogeographically it is related to the Cyclades (see below, Palaeogeography of the Cyclades), politically it belongs to Dodecanissos. The island is uninhabited, except for an elderly lady. No caves have ever been documented.

ETymology. - The new species name refers to its collector, Alexandros Margiolis.

Diagnosis. - This species is similar to D. kikladica Di Russo \& Rampini, n. sp. and D. naxia differing mainly in the leg spinulation, the shape of the tenth tergum, showing two wide triangular lobes, and in the shape of the subgenital plate, which is strongly sclerotized on the external margins. The epiphallus is similar to that of D. kikladica Di Russo \& Rampini, n. sp. but its plica dorsalis differs, having strong denticles on the arched apical lobe.

\section{DESCRIPTION}

Male

Size relatively big. Body brown-yellowish. Legs elongated, femora unarmed. Fore tibiae armed with 2/4 spines on both sides of lower edge, 2/2 spines along upper edge and a pair of apical spurs of equal length. Mid tibiae with $2 / 2$ short spines on both sides of upper edge, 3/4 spines along lower edge and two apical spurs similar to those of fore tibia. Hind tibiae with $17 / 18$ spines of varying length on both sides of upper edge and 2/3 homogeneous spines along lower edge. Posterior edge of tenth tergum with two wide triangular lobes separated by a short concavity in the middle (Fig. 3A). Subgenital plate globular, with two rounded lobes, strongly sclerotized holding two thickened cylindrical styli (Fig. 3B, C). Epiphallus sclerotized having a cylindrical median process, acute at apex and similar to that of D. kikladica Di Russo \& Rampini, n. sp. (Fig. 3D, E). Plica dorsalis, on the whole, similar to that of D. kikladica Di Russo \& Rampini, n. sp. with a conical protuberance in the middle but differs in having strong denticles on the apical lobe (Fig. 3F).

Length (mm): body 16.70; pronotum 3.6; fore femora 18.00; middle femora 17.50; hind femora 26.50; fore tibia 19.00; middle tibia 20.00; hind tibia 34.8; hind tarsus 11.8; hind basitarsomere 6.00 .

\section{Female}

Unknown.

\section{REMARK}

An amazing synchronicity of events led to the discovery of this new species, unfortunately related with the tragic death of three young men. In the first night hours of 12 February 2016, a military helicopter crashed on the uninhabited island of Kinaros, a few tenths of meters from the highest point. The three members of the crew, officers of the Greek Navy, were killed instantly and their bodies were hurled onto the rocky slope. Alexandros Margiolis, an experienced speleologist and a member of the Ypogaia Caving Group, was part of the Special Unit of Hellenic Fire Service that flew in from Athens to recover the bodies. He was familiar with cave crickets, as in the previous months he had taken part in a few collecting trips in caves of mainland Greece, along with Sotiris Alexiou and Stylianos Zacharias. The rescuers had to spend one night on this inhospitable rock during which an unpleasant very humid air was blowing from the east. During the first after dark hours, Margiolis was fortunate enough to notice with his flashlight a cave cricket quickly moving on the rocky terrain, next to him. Being aware of the importance of his observation he collected the specimen, which was kindly given to the authors through Stylianos Zacharias.

Dolichopoda are strongly cave dependant insects and only in the north part of their distribution range are they often encountered outside, in moist woods and ravines. Only one other record exists within Greece of an epigean Dolichopoda specimen, on Mt Athamanio, Epirus, where the moist woods of the outside environment and the climatic conditions, are significantly friendlier (Allegrucci et al. 2009; Di Russo et al. 2014). In regions like the Eastern Cyclades, phrygana is the common habitat type and forests are completely absent. The climate is very dry (especially during summer months) but the relative humidity of the air can be significant (Sfenthourakis 1996). More than that, no cave is known on Kinaros and according to the only 

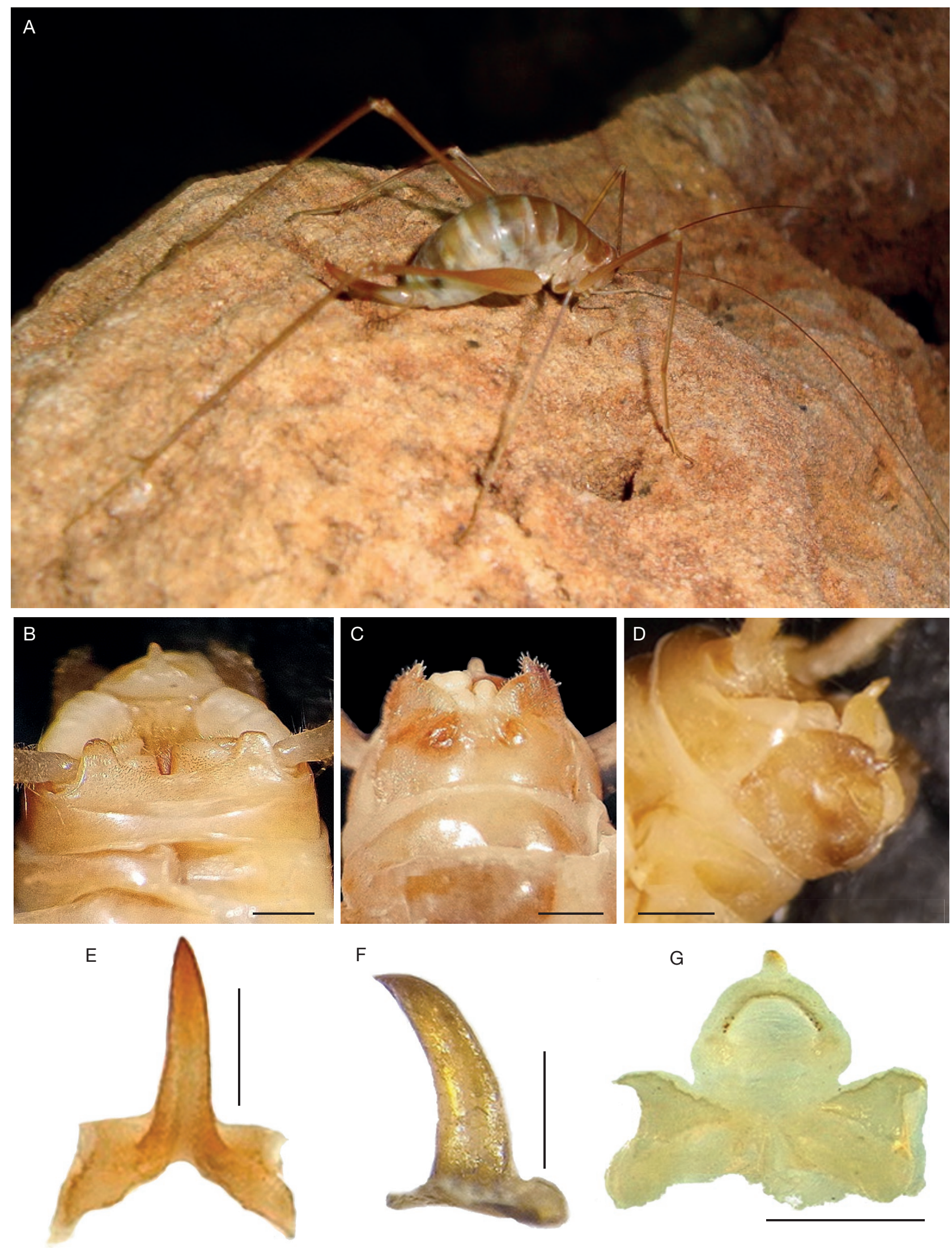

FIG. 2. - A, habitus female of Dolichopoda kikladica Di Russo \& Rampini, n. sp. (not collected); B, male tenth tergum; C, male subgenital plate (ventral view); D, male subgenital plate (lateral view); E, median process of epiphallus (dorsal view); F, median process of epiphallus (lateral view); G, plica dorsalis. Scale bars: $1 \mathrm{~mm}$. Photo by G. Anousakis (A). 

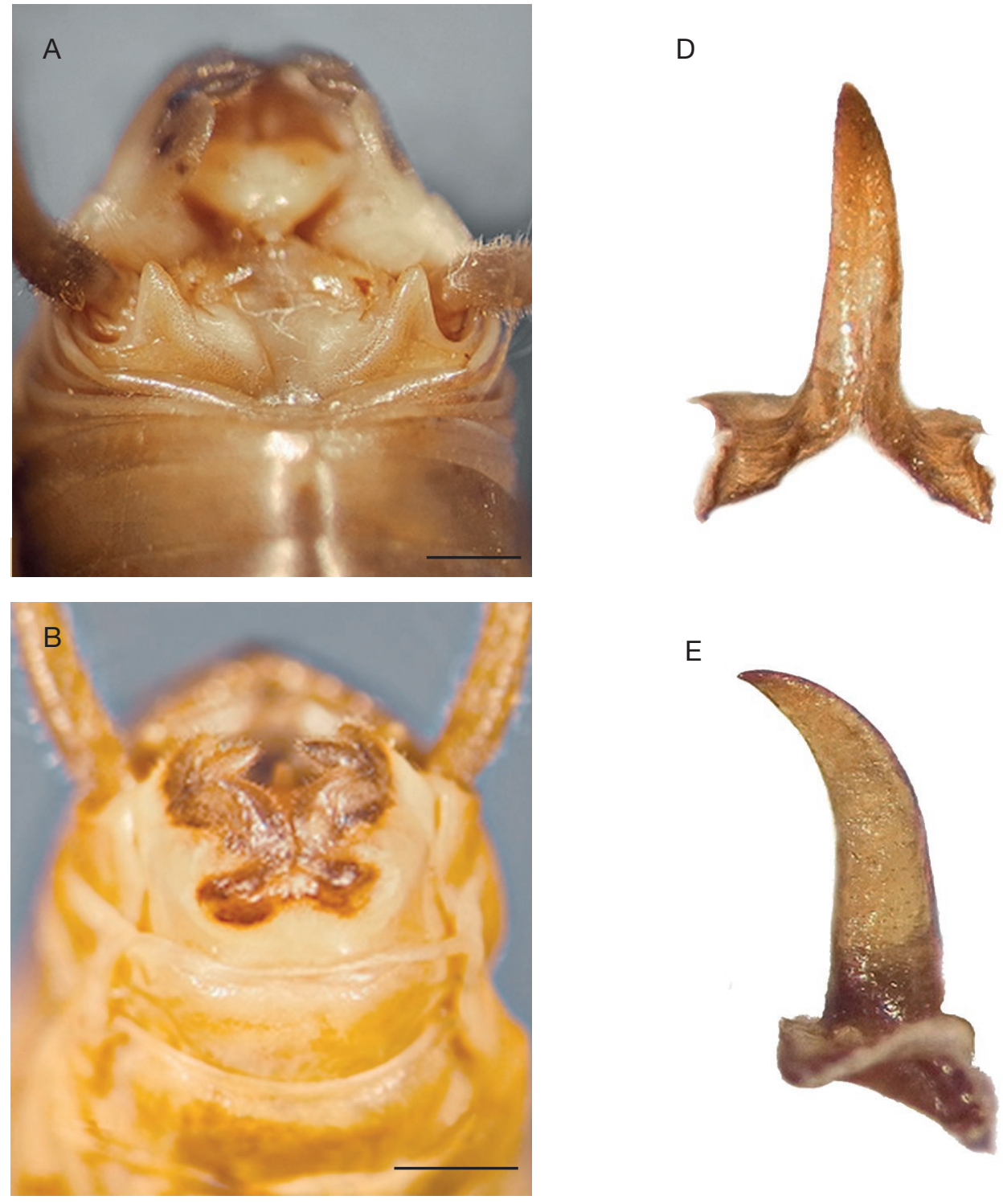

\section{E}
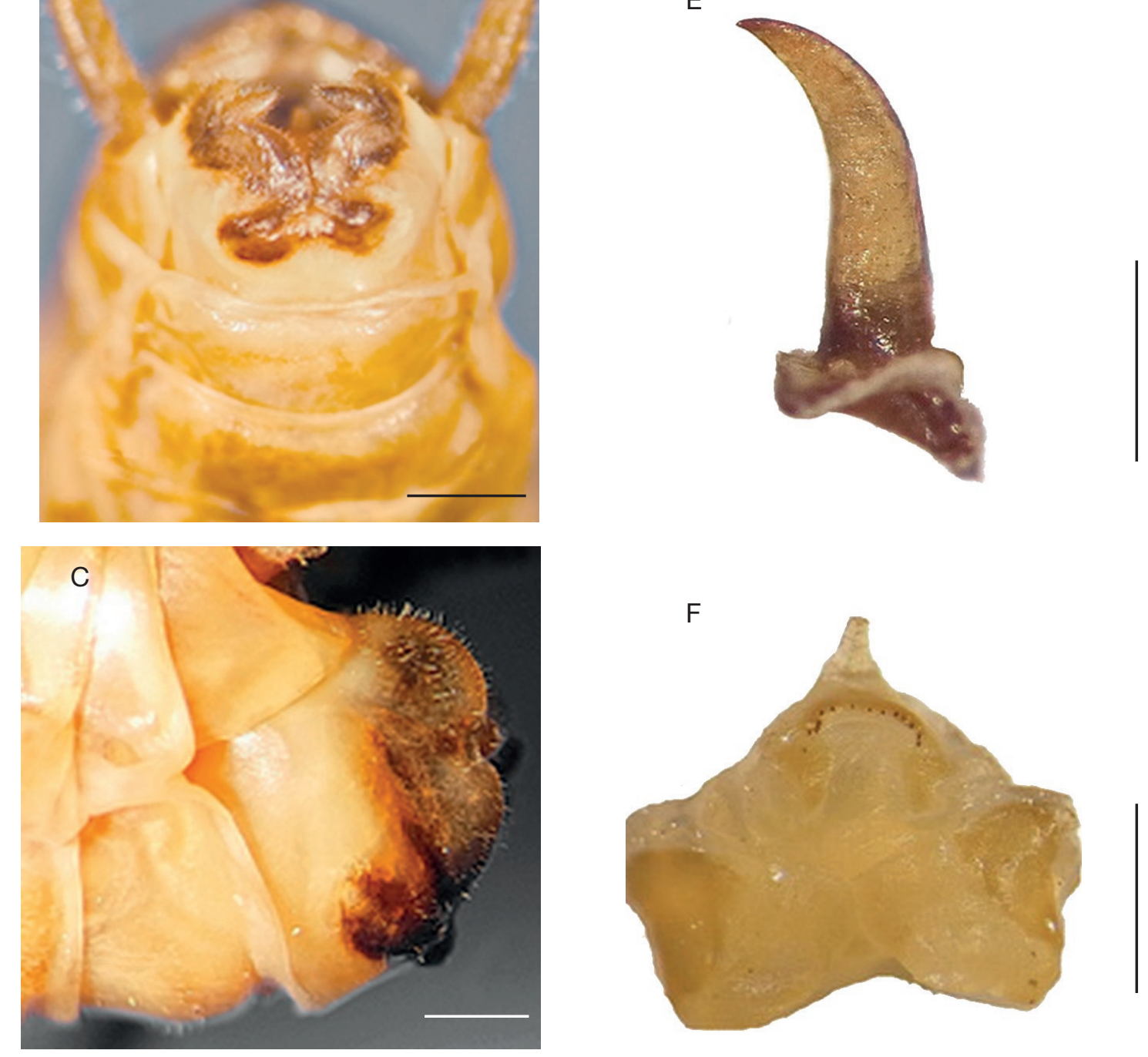

FIG. 3. - Dolichopoda margiolis Di Russo \& Rampini, n. sp.: A, male tenth tergum; B, male subgenital plate (ventral view); C, male subgenital plate (lateral view); D, median process of epiphallus (dorsal view); E, median process of epiphallus (lateral view); F, plica dorsalis. Scale bars: $1 \mathrm{~mm}$. 
inhabitant of the island (the elderly lady born and raised on Kinaros, pers. comm. with Margiolis) only a small rock shelter exists, around $200 \mathrm{~m}$ lower than where the specimen was collected. Thus, it is reasonable to assume that the population of $D$. margiolis Di Russo \& Rampini, n. sp. inhabits either an unknown subterranean hollow space or the network of fissures and crevices of Kinaros (or most likely both), where the relatively stable conditions of temperature and humidity allow for the successful conclusion of its life circle.

\section{Dolichopoda christos-nifoni \\ Di Russo \& Rampini, n. sp.}

(Fig. 4)

urn:Isid:zoobank.org:act:3D83A120-FF73-457B-BF6C-BDAD795FC6FF

TyPe MATeRial. - Holotype. Greece, Kiklades, Andros Isl., Aladinos, Aladinou Cave, 1 ơ, 02.XII.2015, S. Alexiou leg. (MZUR).

OTHER MATERIAL EXAMINED. - 1 9, 02.XII.2015 (MZUR); 2 \%, 7 nymphs, 18.VI.2015 (ZMUA). Same locality and collector as the holotype.

TYPE LOCALITY. - Andros is the northernmost island of the Cyclades and with a size of $380 \mathrm{~km}^{2}$, it is the second largest after Naxos. It lies close to the large island of the west Aegean, Evvia (Euboea), separated from the latter by the Kafireas Straits, a channel of $12 \mathrm{~km}$. Mt Gerakones $(680 \mathrm{~m})$ is one of the four small mountains of Andros island, the highest being Mt Kouvaras (or Petalon), which reaches $994 \mathrm{~m}$. Between these two mountains lies Messaria, the central valley of Andros. At the foot of northern slopes of Mt Gerakonas, facing Messaria, the cave Aladinou or Foros is located, at an altitude of $120 \mathrm{~m}$ a.s.l., near the village Aladinou and about $4 \mathrm{~km}$ from Chora. In contrast to most of the Cyclades, the rocks on Andros are mostly schists of various types (Snogerup et al. 2006). Limestone is found only in small areas, the most extensive being a row of low cliffs along the northwest flank of Mt Gerakones.

The cave Aladinou is one of the biggest caves found in the Cyclades, filed $15^{\text {th }}$ in the official list of the Hellenic Speleological Society (HSS) of chronologically discovered caves in Greece. The cave was first explored in 1937 by Ioannis and Anna Petrochilou. In 1962, A. Petrochilou and S. Diakogiannis, as members of the H.S.S. were assigned to chart the cave. The results were published one year later (Petrochilou 1963). The cave has a size of about $500 \mathrm{~m}^{2}$. Temperature inside the cave is $16-17^{\circ} \mathrm{C}$ and humidity is $75 \%$. The cave has stalactites, stalagmites, helictites, hanging rocks, colorful limestone and gour formations. The cave is maintained by the Cultural Society of Aladinou 'Agia Triada' and a permit is needed to enter. A traditionally paved road a few hundred meters long, leads from the village to the cave, over an old bridge, that crosses the river. The entrance of the cave is artificially blocked, in order to prevent damage from visitors. Steps made of concrete lead to the main chamber and artificial light has been placed in this first part. There is no guano present on the floor and only one bat was observed, Rhinolophus ferrumequinum (Schreber, 1774) entering obviously from a smaller natural entrance.

ETYMOLOGY. - The new species name refers to one of the authors' (SA) son, Christos-Nifon Alexiou, who at the age of 7, accompanied his father and actively took part in the collection of specimens from Andros.
DiAGNOSIS. - The size is relatively small with the hind legs elongated. This species shows a combination of morphological characters that, in a way, appears similar to those of the Evvian Dolichopoda, while others are close to the Cycladic species. In particular, D. christos-nifoni Di Russo \& Rampini, n. sp. shares the bifurcate apex of the epiphallus and the shape of the female subgenital plate with $D$. makrykapa and D. ochtoniai from Evvia. On the contrary, it shares the tenth tergum and the plica dorsalis with the other species of the Cyclades (Paros, Naxos) and the species from Kinaros (Dodecanissos).

\section{DESCRIPTION}

Male

Size relatively small. Body color yellow-brown with the posterior margins of the terga darker. Legs long, slender and yellowish in color with the femora unarmed. Fore tibiae armed with 5/6 spines on both sides of inferior edge, $4 / 5$ spines on upper edge, a pair of spurs of equal length on apex. Mid tibiae with 3/7 short spines on both sides of upper edge, 4/6 spines on lower edge and two apical spurs similar to those of fore tibiae. Hind tibiae longer, with $21 / 23$ spines of varying length on both sides of upper edge and $1 / 1$ homogeneous spines on the lower edge. Posterior edge of the tenth tergum with two elongated triangular lateral lobes with an acute apex (Fig. 4A).

Subgenital plate globular at bottom, with a large median incision that runs for half of total length; symmetrical lateral lobes triangular with rounded posterior edges, styli cylindrical and short (Fig. 4B, C). Epiphallus sclerotized showing a relatively short median process, with a bifurcated apex; from the side, median process slightly curved; basal processes quite well developed (Fig. 4D, E). Plica dorsalis similar to that of $D$. margiolis Di Russo \& Rampini, n. sp., differing by being strongly sclerotized on the basal lobes and by having cylindrical protuberance occurring in the middle of apical part (Fig. 4F).

Length (mm): body 13.5; pronotum 3.5; fore femora 13.8; middle femora 13.0; hind femora 21.4; fore tibia 14.4; middle tibia 14.6; hind tibia 24.8; hind tarsus 9.7; hind basitarsomere 5.7 .

\section{Female}

Body length ranging between 12.3-14 mm (ovipositor excluded) and general form similar to male. Tergum IX not complete in the middle and covered by a wide extension of the tergite VIII. Subgenital plate trapezoidal (Fig. 4G), with the distal part more sclerotized, bilobate with an incision on the middle of the posterior margin.

Ovipositor, uniformly curved, $9 \mathrm{~mm}$ length in average, showing a pointed apex curved upwards. Shorter inferior valves, slightly curved on the superior edge, with 15-17 denticles (Fig. 4H).

\section{REMARK}

The fauna of the Cave Aladinou is very poor and the population of D. christos-nifoni Di Russo \& Rampini, n. sp. seems to be sparse. On our first visit, no adult male could be traced and a second visit was needed in order to locate and collect adult males. 

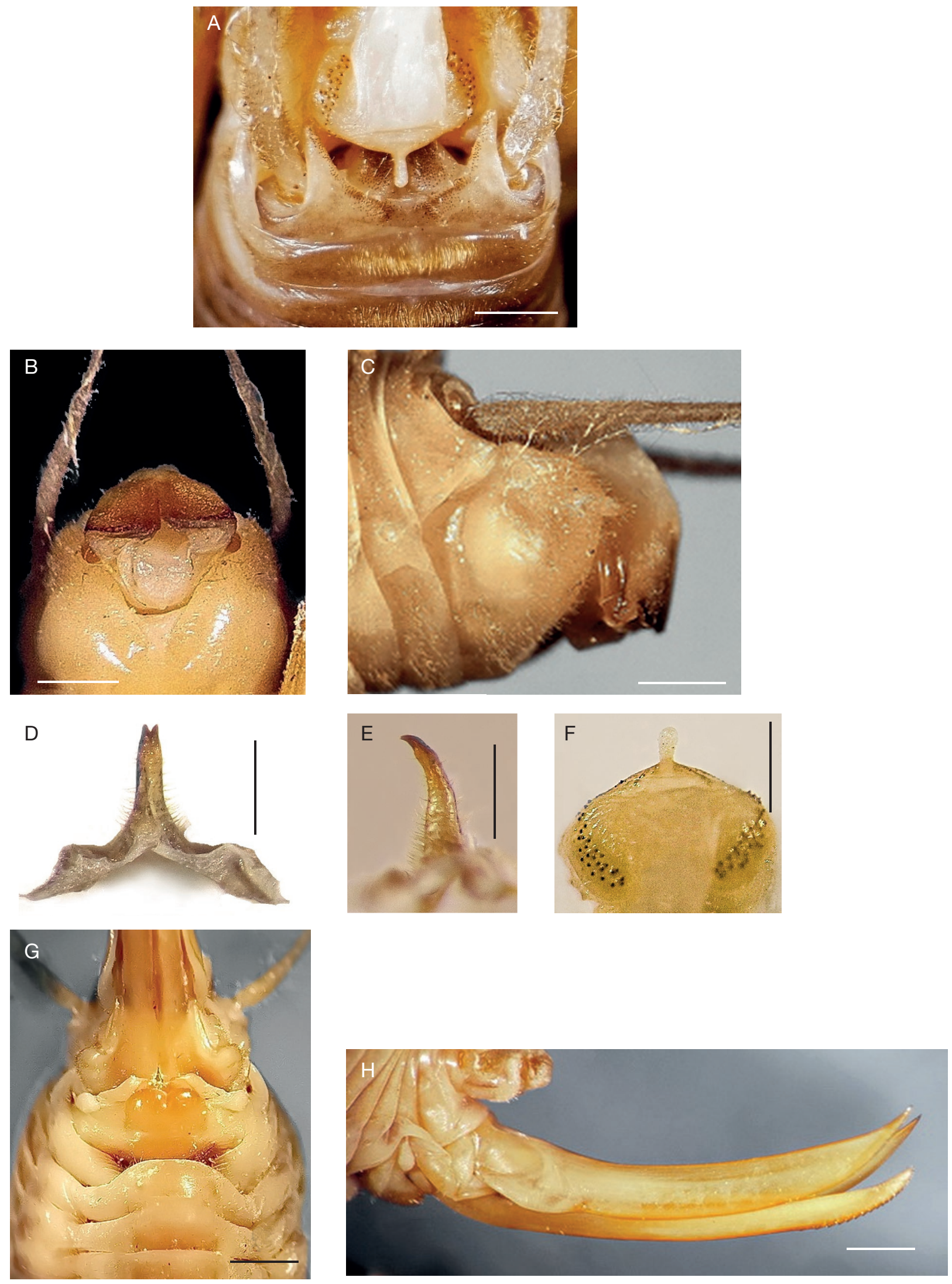

FIG. 4. - Dolichopoda christos-nifoni Di Russo \& Rampini, n. sp.: A, male tenth tergum; B, male subgenital plate (ventral view); C, male subgenital plate (lateral view); D, median process of epiphallus (dorsal view); E, median process of epiphallus (lateral view); F, plica dorsalis; G, female subgenital plate; $\mathbf{H}$, ovipositor (lateral view). Scale bars: $1 \mathrm{~mm}$. 


\section{DISCUSSION}

\section{COMPARISONS OF THE NEW SPECIES WITH THE OTHER} DOLICHOPODA FROM THE AEGEAN AREA

This paper is focused on the description of three new species of Dolichopoda cave crickets, two from the Cyclades islands Andros and Paros, one from Kinaros in the Dodecannissos archipelagos. In particular the new species from Paros (D. kikladica Di Russo \& Rampini, n. sp.) and from Kinaros (D. margiolis Di Russo \& Rampini, n. sp.) show strong similarities with $D$. naxia from Naxos and the other east Aegean species. These species, together with $D$. giulianae and D. kalithea from Samos, D. calidnae from Kalimnos and in some extent also with $D$. paraskevii from Crete, form an homogenous group sharing a series of morphological features. All these species are characterized by enlarged lateral lobes of the tenth tergum, median process of the epiphallus cylindrical more or less flattened and the plica dorsalis formed by two basal lobes slightly sclerotized with an arched apical lobe holding strong denticles. These characters are shared also by the Turkish species D. sutinii Rampini \& Taylan, 2012 (Rampini et al. 2012), endemic of a cave on the western coast of Turkey just in front of the Samos island (Sutini cave, Selçuc, Izmir).

On the other hand the species D. christos-nifoni Di Russo \& Rampini, n. sp. from Andros shows a combination of morphological characters that partly resemble those found in the Cycladic Dolichopoda and partly found in species from Evvia. Particularly, D. christos-nifoni Di Russo \& Rampini, n. sp. shares the tenth tergum and the plica dorsalis with the Cycladic species (Paros and Naxos), the species from Kinaros and the other from the eastern Aegean. On the contrary the new taxon shares the bifurcate apex of the median process of the epiphallus and the shape of female subgenital plate with D. makrikapa and D. ochtoniai from Evvia (Alexiou et al. 2015). The bifurcate apex of the epiphallus and the globular shape of the female subgenital plate are two distinctive characters of the Petrochilosina group (sensu Boudou-Saltet, 1983), inhabiting caves from Beotia, Attiki and Evvia.

\section{Paleogeography of the Cyclades}

The Cycladic islands are located in the central Aegean Sea, Greece. They are set on a shallow, partly submerged, undulating plateau (the Cyclades Plateau), with a maximal depth of less than $250 \mathrm{~m}$ and generally less than $200 \mathrm{~m}$. The higher elevations are in the east and the lower in the west (Gaki-Papanastasiou et al. 2010). Like most of the genera present in the Aegean today, Dolichopoda have diversified during the Plio-Pleistocene periods, the last $5 \mathrm{My}$. Their current diversity and their distribution pattern are in accordance with the complex paleogeographic history of the Aegean. A succession of extinction, speciation, dispersal and vicariance events, provoked by mainly eustatic events (submergence and reemergence of landmasses), has probably led to non-adaptive radiation of the genus (Sfenthourakis 1996; Allegrucci et al. 2009; Poulakakis et al. 2015).

Land emerged in the Aegean region for the first time during the orogenesis that took place in southern Europe during the Oligocene (35-25 Mya). A continuous landmass, Aegeis (Agaïs), occupied the area between the present day Ionian Islands and the Anatolian Plateau. During the Miocene, the Central Aegean was a very shallow landmass, with extensive emerged regions and small elongated basins. Climate conditions were warm and humid. In the middle Miocene, around $10 \mathrm{Mya}$, an event of major importance for Aegean life, took place: the formation of the Mid-Aegean Trench (MAT) that started as a result of the collision of the African and Arabian Plates with the Eurasian Plate. The MAT separated the Greek mainland together with present day Evvia, Crete and the Cyclades from the Anatolian Plateau, including the present day Eastern Aegean islands (Hellwig 2004; Gaki-Papanastassiou et al. 2010; Poulakakis et al. 2015). This uplift of the Anatolian Plateau has been suggested as the event that triggered the speciation of the ancestors of Aegean Dolichopoda, within the Anatolian Plate (Allegrucci et al. 2009).

The increasing aridity of the Mediterranean climate throughout the Miocene, peaked at the end of that period and was further enhanced by the Messinian Salinity Crisis (6-5 Mya). Most of the Aegean, as well as the largest part of the Mediterranean, was desiccated. Climate conditions were warm and humid and the rainfall rates were high. New migration opportunities were presented for organisms to radiate through steppe-like environments (Hellwig 2004; Poulakakis et al. 2015). According to Allegrucci et al. (2009), those exactly are the opportunities that facilitated Dolichopoda populations to colonize the area of the Aegean from Anatolia.

The end of the Messinian Salinity Crisis, at the end of Miocene, triggered speciation of Dolichopoda in the Aegean. The Mediterranean became a sea again, flooded through Gibraltar. Islands formed in the place of mountains. The sea separated the Cyclades from Crete and the mainland. The Cyclades Plateau split into two parts, with Paros belonging to the northern and Naxos to the southern part. Kinaros is believed to have submerged during this period. Ancestral Dolichopoda forms became isolated on several islands. This time the flooding of the Aegean was long and extended. Climatic conditions became cooler and arid throughout the Pliocene while, since the late Pliocene, a climate like that of today appeared, with dry and hot summers. The Cyclades Plateau became isolated at least $2 \mathrm{Mya}$ ago. During the Pleistocene (2.5 Mya-10 000 ya) the repeated glacial-interglacial events led to repeated changes of sea level, exposing the sea floor during glacial periods, thus uniting existing islands into more extensive landmasses or even with the mainland, and facilitating gene flow among previously isolated populations. Almost 50-60\% of the present Aegean Sea was above sea level, and extensive drainage systems developed, together with delta plains and large lakes. Land bridges connected the Cyclades Plateau, westwards with Evvia and the mainland and eastwards with Anatolia and East Aegean Islands. On the other hand, during interglacial climatic conditions the sea level rose, creating smaller islands again, submerging exposed land and isolating populations (Sfenthourakis 1996; Hellwig 2004; Lykousis 2009; Allegrucci et al. 2009; Kapsimalis et al. 2009; Poulakakis et al. 2015). 


\section{Historic BIOGEOGRAPHY}

Paros and Naxos, despite their geographic proximity, harbor two different, yet related, species, D. kikladica Di Russo \& Rampini, n. sp. and D. naxia. The species inhabiting Andros, D. christos-nifoni Di Russo \& Rampini, n. sp., shows affinities with the species of Evvia as well as with the other Cycladic species. Dolichopoda margiolis Di Russo \& Rampini, n. sp. from Kinaros is also related to the Cycladic D. naxia and D. kikladica Di Russo \& Rampini, n. sp. The four aforementioned species seems to be isolated from each other at least since the Last Glacial Period (LPG, 20000 ya). During that time, the Cycladic Plateau, with present day Andros, Paros and Naxos, had the form of a 'mega-island'. Kinaros, with Amorgos, formed a different island, at the periphery of the 'mega-island', on the edge of the west side of the MAT. In the central part of the 'mega-island' there were several depressions, low-lying and flat plains (or even palaeolakes), which may have already fragmented the Dolichopoda populations into isolated highland areas, even before the actual breaking up of the 'mega-island' into separate islands. This unfavorable landscape and the cold, dry climatic conditions, led to decreased gene flow among terrestrial populations and prevented radiation. Paros-Naxos formed a highland, isolated to the north and south by the two main plains of the 'mega-island'. The formation of the present day isolated islands started after the end of LGP, around $18000 \mathrm{ya}$, with the progressive flooding of the 'mega-island' with sea water and the rising of sea level. The climate conditions became warmer and more humid, the Plateau submerged, leaving some of its highlands exposed as islands. Paros became detached from Naxos around 8000 ya and Andros became an island at about 10000 ya. Kinaros detached from Amorgos around 12000 ya (Lykousis 2009; Gaki-Papanastassiou et al. 2010; Kapsimalis et al. 2009; Poulakakis et al. 2015).

Georgopoulou et al. (2016) outline the 'intermediate' zoogeographic position of Andros based on a survey of freshwater Gastropoda of the island and Sfenthourakis (1996) lists some species of terrestrial isopods that are indicative of a recent connection with mainland Greece. Similar evidence is provided by phytogeographic studies (Snogerup et al. 2006).

Kinaros has been isolated long before the LGM. It has been faunisticaly explored to some extent. Along with Levitha and North Amorgos, Kinaros has been designated as an Important Bird Area by the Hellenic Ornithological Society, mainly because of the presence of reproductive communities of Larus audouinii Payraudeau, 1826 and Falco eleonorae Géné, 1839. Other than avifauna, several faunistic elements regarding Gastropoda, Isopoda and Coleoptera have been known to science (Sfenthourakis 1996; Trichas 2008). Dolichopoda margiolis Di Russo \& Rampini, n. sp. is the only Orthoptera taxa recorded so far and seems to be the largest invertebrate known from the island. The nearby Amorgos harbors its own fauna (van der Geer et al. 2014) and the same can be assumed for its tiny neighbour. The fauna of Kinaros is relatively rich for its small size and several of its elements demonstrate a biogeographic connection with the Cyclades (Sfenthourakis 1996), similar to the evidence provided by its cave crickets population. The land snails of the genus Zonites Montfort, 1810 on Kinaros seem to be closely related to members of the genus from Amorgos and Naxos (Kornilios et al. 2009). Further support is provided by the presence of the Cycladic endemic coleopteran species Dendarus sinuatus (Mulsant \& Rey, 1854) (Trichas 2008) and of the wall lizard genus Podarcis Wagler, 1830, a genus that colonized the Balkans and the Aegean from the northwest, after the formation of the MAT, and has not been able to colonize the east Aegean islands (Poulakakis et al. 2003). Nevertheless, a more complex biogeographic position of the Kinaros fauna is expected, due to the existence of land bridges in different geological periods, that have probably connected the island with the eastern Aegean islands and Anatolia. In fact, this is shown by the presence of the endemic land snail Albinaria werneri (Fuchs \& Kaüfel, 1936) (synonym of fuchskaeufeli H. Nordsieck, 1977), which according to Nordsieck (personal communication, 4.X.2017) 'as already stated by Fuchs \& Käufel 1936 (Archiv für Naturgeschichte, NF, 5 [4] [: 600]) is closely related to $A$. lerosiensis (L. Pfeiffer, 1841) from Dodecanissos (islands of Leros, Patmos, Kalimnos and Kos) and Turkey, region of Bodrum'. Kinaros, with a maximum elevation of less than 300 meters, is expected to have submerged and reappeared several times during the Plio-Pleistocene. So, events of extinction and re-colonization of all terrestrial life forms from the island are expected to have occurred repeatedly. It is reasonable to assume that Dolichopoda margiolis Di Russo \& Rampini, n. sp. has evolved from a population that colonized the island from (or through) Amorgos. Amorgos is known to harbor a Dolichopoda population still unknown to science, documented by an autopsy in caves by the Ephorate of Palaeoanthropology and Speleology of Greece (Economou 2008).

\section{Acknowledgements}

We express our thanks to Alexandros Margiolis (Athens), Giorgos Anousakis (Paros), Basilis Tsigonias (Paros), Anna Tsigonia (Paros), Giorgos Trivizas (Paros), Froso Kaladami (Andros) and the Cultual Association 'Agia Triada' (Andros) for offering assistance to our collecting trips or collecting for us. Thanks are due to Stylianos Zacharias (Athens), who also improved the English language. Laure Desutter-Grandcolas and an anonymous reviewer have offered suggestions and useful comments to the manuscript.

\section{REFERENCES}

Alexiou S., Di Russo C. \& Rampini M. 2013. — The family Rhaphidophoridae (Orthoptera) in Greece. Parnassiana Archives 1: 51-58. AleXIOU S., Di Russo C. \& RAMPINI M. 2015. - The cave crickets of of the genus Dolichopoda from Evvia and Skyros islands: formal description of D. octhoniai and D. saraolacosi (Orthoptera: Rhaphidophoridae). Fragmenta entomologica 47 (2): 133-137. https://doi.org/10.4081/fe.2015.141

Allegrucci G., Rampini M. Gratton P., Todisco V. \& SBordoni V. 2009. - Testing phylogenetic hypotheses for reconstructing the evolutionary history of Dolichopoda cave crickets in the eastern 
Mediterranean. Journal of Biogeography 36: 1785-1797. https:// doi.org/10.1111/j.1365-2699.2009.02130.x

Boudou-Saltet P. 1970. — Les Dolichopodes (Orth. Rhaph.) de Grèce. II. Une nouvelle espèce: D. vandeli. Biologia gallohellenica 3: 89-97.

Boudou-Saltet P. 1971a. - Les Dolichopodes de Grèce. III. Dolichopoda cassagnaui, n. sp. Bulletin de la Société d'Histoire naturelle de Toulouse 107: 295-300.

Boudou-Saltet P. 1971b. - Les Dolichopodes de Grèce. IV. Decouverte de la femelle de D. insignis Chop. Bulletin de la Société d'Histoire naturelle de Toulouse 107: 615-618.

Boudou-SAlteT P. 1972a. - Les Dolichopodes (Orth. Rhaph.) de Grèce. V. Deux nouvelles espèces: Dolichopoda naxia et D. steriotisi. Biologia gallohellenica 4: 99-108.

Boudou-Saltet P. 1972b. - Les Dolichopodes (Orth. Rhaph.) de Grèce. VII. Nouvelles espèces du Péloponnèse. Bulletin de la Société d'Histoire naturelle de Toulouse 108: 420-425.

Boudou-SalteT P. 1973a. - Les Dolichopodes (Orth. Rhaph.) de Grèce. VI, D. annae, nouvelle espèce de Thessalie. Biologia gallo-hellenica 4: 169-174.

Boudou-Saltet P. 1973b. - Les Dolichopodes (Orth. Rhaph.) de Grèce. VIII. Nouvelles espèces de Crète. Biologia gallo-hellenica 5: 57-63.

Boudou-Saltet P. 1980. — Les Dolichopodes (Orth. Rhaph.) de Grèce. IX. Une espèce nouvelle en Eubee: D. makrykapa. Biologia gallo-hellenica 9: 123-134.

Boudou-SAlteT P. 1983. - Sur les Dolichopoda (Orth. Raph.) du sous-genre Petrochilosina. Mémoires de Biospéologie 10:321-323.

CHOPARD L. 1934. - Diagnoses d'Orthoptères cavernicoles nouveaux. Bullettin de la Société entomologique de France 39: 137-139.

CHOPARD L. 1954. - Contribution à l'étude des Orthoptères cavernicoles. Notes biospeologiques 9: 27-36.

Chopard L. 1955. - Les Dolichopodes de Grèce. Notes biospeologiques 10: 31-34.

CHOPARD L. 1964. - Description d'Orthoptères cavernicoles de Grèce. Bullettin de la Société entomologique de France 69: 17-20.

Di Russo C., Rampini M. \& Cobolli M. 2014. — The cave crickets of Greece: a contribution to the study of Southern Balkan Rhaphidophoridae diversity (Orthoptera), with the description of a new species of Troglophilus Krauss, 1879. Biodiversity Journal 5 (3): 397-420.

ECONOMOU A. A. 2008. - Fauna of the Greek caves. Ephorate of Palaeoanthropology and Speleology of the Ministry of Culture, Education and Religious Affairs, Athens. [In Greek].

Gaki-Papanastassiou K., Evelpidou N., Maroukian H. \& VASSILOPOULOS A. 2010. - Palaeogeographic Evolution of the Cyclades Islands (Greece) During the Holocene, in GreEN D. (ed.). Coastal and Marine Geospatial Technologies. Coastal Systems and Continental Margins, vol 13. Springer, Dordrecht: 451.

Galvagni A. 2002. - Una nuova Dolichopoda (s. str.) di Grecia: D. pavesi, n. sp. dell'isola di Kefallenia (Insecta Orthoptera Rhaphidophoridae). Atti dell'Accademia Roveretana degli Agiati, a. 252, ser. VIII, vol. II, B: 5-16.

Georgopoulou E., GlÖER P. \& Simaiakis S. M. 2016. — Contribution to the freshwater gastropods of the island of Andros in the northern Cyclades (Aegean islands, Greece). Folia Malacologica 24 (4): 275-286. https://doi.org/10.12657/folmal.024.023

Gorochov A. V. \& UnAL M. 2015. - A new species of the genus
Dolichopoda (Orthoptera: Rhaphidophoridae) from Teke peninsula, Turkey. Poceeding of Zoological Institute RAS. 139: 126-131.

HellWIG F. H. 2004. - Centaureinae (Asteraceae) in the Mediterranean- history of ecogeographical radiation. Plant System Evolution Journal 246: 137-162.

Kapsimalis V., Pavlopoulos V., Panagiotopoulos I., Drakopoulou P., Vandarakis D., Sakelariou D. \& Anagnostou C. 2009. - Geoarchaeological challenges in the Cyclades continental shelf (Aegean Sea). Z. Geomorph. N.F. 53 (1): 169-190.

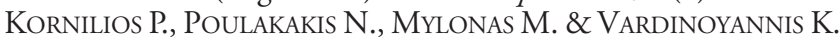
2009. - The phylogeny and biogeography of the genus Zonites Montfort, 1810 (Gastropoda: Pulmonata): preliminary evidence from mitochondrial data. Journal of Molluscan Studies 75: 109117. https://doi.org/10.1093/mollus/eyp003

LYKOUSIS V. 2009. - Sea-level changes and self break prograding sequences during the last $400 \mathrm{ka}$ in the Aegean margins: Subsidence rates and palaeogeographic implications. Continental Self Research 29: 2037-2044. https://doi.org/10.1016/j.csr.2008.11.005

Petrochilou A. 1963. - Spileon 'Foros', Aladinou-Androu. Bulletin of Hellenic Speleological Society VII 3 [in Greek].

Petrochilou A. 1970. - Spileon ton 'Demonon' i Kalampaka Parou. Bulletin of Hellenic Speleological Society XI 5 [in Greek].

Poulakakis N., Lymberakis P., Antoniou A., Chalkia D., Zouros E., Mylonas M. \& Valakos E. 2003. - Molecular phylogeny and biogeography of the wall-lizard Podarcis erhardii (Squamata: Lacertidae). Molecular Phylogenetics and Evolution 28: 38-46. https://doi.org/10.1016/S1055-7903(03)00037-X

POUlaKaKis N., Kapli P., LyMberakis P., TRICHAS A., VARDINOYIANNis K., SfenthouraKis S. \& Mylonas M. 2015. - A review of phylogeographic analyses of animal taxa from the Aegean and surrounding regions. Journal of Zoological Systematics and Evolutionary Research 53 (1): 18-32. https://doi.org/10.1111/jzs.12071

Rampini M., Di Russo C., TaYlan M. S., Gelosa A. \& Cobolli M. 2012. - Four new species of Dolichopoda Bolivar, 1880 from Southern Sporades and Western Turkey (Orthoptera, Rhaphidophoridae, Dolichopodainae). Zookeys 201: 43-58. https://doi. org/10.3897/zookeys.201.2609

SFENTHOURAKIS S. 1996. - A biogeographical analysis of terrestrial isopods (Isopoda, Oniscidea) from the central Aegean islands (Greece). Journal of Biogeography 23: 687-698. https:// doi.org/10.1111/j.1365-2699.1996.tb00029.x

Snogerup S., Snogerup B., Stamatiadou E., Von Bothmer R. \& GUSTAFSON M. 2006. - Flora and vegetation of Andros, Kikladhes, Greece. Annales Musei Goulandris 11: 85-270.

Trichas A. 2008. - The genus Dendarus Latreille, 1829 (Coleoptera, Tenebrionidae: Dendarini) in Greece (A systematic account of the genus with description of a new species and four new systematic combinations), in MAKAROV S. E.\& DimitrijEVIĆ R. N. (eds). Advances in Arachnology and Developmental Biology. SASA, Belgrade \& UNESCO MAB Serbia. Vienna-Belgrade-Sofia, Monographs 12: 417-462.

Van Der Geer A. A. E., Lyras G. A., Van Den Hoek Ostende L. W., De Vos J. \& Drinia H. 2014. - A dwarf elephant and a rock mouse on Naxos (Cyclades, Greece) with a revision of the palaeozoogeography of the Cycladic Islands (Greece) during the Pleistocene. Palaeogeography, Palaeoclimatology, Palaeoecology 404: 133-144. https://doi.org/10.1016/j.palaeo.2014.04.003 